\title{
Emberkísérlet cigányokkal?
}

Kassán 1941-ben gyógyszerek klinikai tesztelése/kipróbálása folyt. Az első kísérletben 124 (köztük gyerekek), a másodikban 48, a harmadikban 36 cigány személy arzenobenzol-érzékenységét vizsgálták. A vizsgálatba bevontak arzenobenzolt és solusalvarsant kaptak. Az első kísérlet során 3 főnél bőrgyulladás, 7 főnél sárgaság és 10 főnél érbeidegzési zavar tünete jelentkezett. A második alkalommal az adag növelése 3 fónél bőrgyulladást, 7 fơnél sárgaságot és 10 fönél érbeidegzési zavart okozott. A harmadik kísérlet során tovább növelték az adagot, ami után 2 főnél bőrgyulladás, 3 fơnél sárgaság, l fơnél ezek együttese és 12 főnél érbeidegzési zavar alakult ki.

A történteket a magát Gervai Gábornak nevező szerző idézte fel az Emberkisérletek Kassán, 1941 címú, az Amaro Drom folyóirat 1991. évi 7. számában megjelent rövid, egyoldalas cikkében (l.ábra). A szerző a kísérletek végzőit is felsorolta: $d r$. Arvayné Szentkirályi Irma, $d r$. Szentkirályi Zsigmond, dr. Habán György és dr. Nagy Imre. A kulcsfigura $d r$. Szentkirályi Zsigmond, aki a történteket dokumentálta, aminek feltalálási helyét a szerző így adta meg: „A cigányok arzenobenzol-érzékenysége. Kassa, 1941.” A cikk ezzel záródik: „A tanúk meghaltak vagy félnek, mert ma is kiszolgáltatottak és megalázottak. A bűnösök pedig megöregedtek, békében és tisztességben. De ne higgye senki, hogy a feledés homályába merülhet a bún, amit egy kiszolgáltatott ember vagy népcsoport ellen követtek el. Mert voltak és mindig is lesznek - hiszem - olyanok, akik kutatnak és keresnek."

Ez magyar orvosok ellen nagyon súlyos vád. Van ok utánajárni, hogy mi is történt valójában.

Ebben azonban nem nyújtott segítséget a dokumentum megnevezése, mert ilyen címen kiadványnak sem az Országos Széchényi Könyvtárban, sem másutt nincs nyoma. Viszont a kassai emberkísérletről Katz Katalin is beszámol egy bekezdés erejéig Visszafojtott emlékezet. A magyarországi romák holokauszttörténetéhez címú könyvének (Budapest, Pont Kiadó, 2005) 29. oldalán: „1941ben embereken végzett kísérletet publikáltak (Szentkirályi, 1941.): emberek arzenobenzol különböző dózisaira mutatott érzékenységét vizsgálták. Tudósítanak az anyag 124, 48, majd 36 roma szervezetébe juttatásáról. A kísérleti alanyok közt gyermekek is voltak. Az összefoglalóban beszámolnak az okozott bajokról: hepatitiszről, bőrgyulladásokról, idegrendszeri elváltozásokról.”

És megadja a forrást: „Szentkirályi, Z. (1941): A cigányok arzenobenzol-érzékenysége. Népegészségügy, 14, 986-994." Ha a 14-es szám, a könyvészeti hivatkozás szabályai szerint, a folyóirat évfolyamát jelöli, akkor a cikk nem 1941-ben, hanem 1933-ban jelent volna meg. Ha az 1941. évi (amely a 22. évfolyam) 14. számát, abban ilyen cikk nincs, a 986-994. oldalszám pedig a 15. és 16. szám között oszlik meg. Tovább keresve eljuthatunk a szeptember 1-jei 17. számban Szentkirályi Zsigmond dr. és Árvayné Szentkirályi Irma: A kassai cigányok veneriás fertőzöttsége címü tanulmányához (1066-1077. oldal), de nem ezt keressük.

Nem volt mit tenni, végig kellett lapoznom a kor orvostudományi szakirodalmát. A keresett cikket végül az Orvostudományi Közlemények 1942. szeptember 12-ei, 17. számának 538-541. oldalán találtam meg.

De mi célt is szolgálhatott a cigányokkal való orvosi kísérletezés, akik amúgy szifiliszesek voltak - amely tényt Gervai említi, Katz azonban nem. És mi is az arzenobenzol és solusalvarsan?

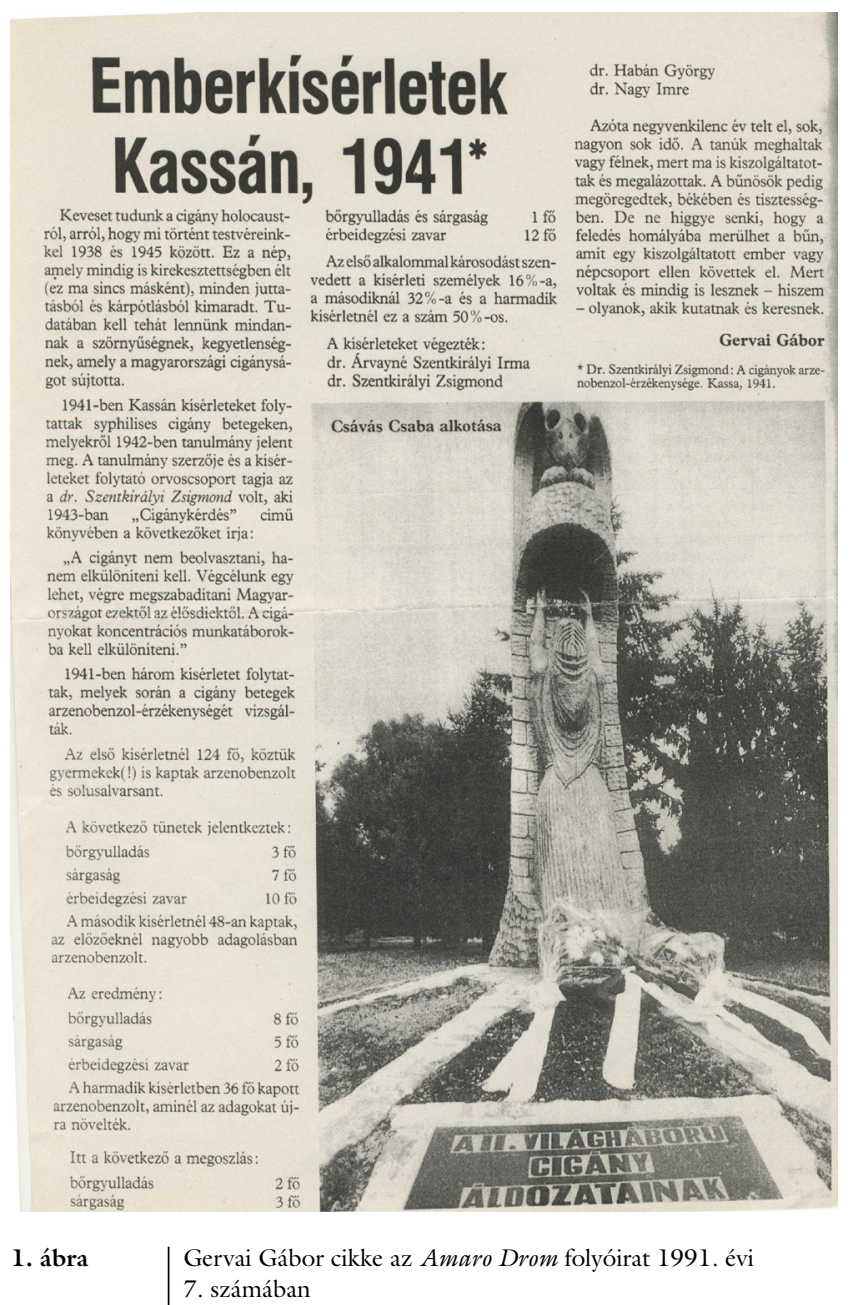


Dr. Szentkirályi Zsigmond régi erdélyi nemesi család sarja, ekként a Komjátszeghy előnév viselésére jogosult, amit nem nagyon viselt, magam is csak a Népegészségügy nekrológjában találkoztam vele. ${ }^{1}$ Apai és anyai ágon is kimagasló szellemi képességekkel megáldott ősök utóda. Azonos nevü nagyapja (1804-1870) bányamérnök, erdélyi bányakapitány, az MTA levelező tagja, Kolozsvár 1867. évi kiegyezés utáni első polgármestere. Apja, Ákos (1851-1933) a kolozsvári gazdasági akadémia igazgatója, az apja nevét kapó fia nyomdokaiba lépve agrárszakember lesz, míg a nagyapja nevét kapó (s majdan nagyapja házsongárdi temetőben lévő sírjába temetett), 1893. február 7-én született Zsigmond a kolozsvári Katolikus Főgimnázium elvégzése után az ottani egyetemen 1915ben orvosi diplomát szerez.

Ekkor már javában folyt az I. világháború: orvosként vonul be, végigcsinálja, helytállásáért több kitüntetést kap, köztük kétszer is ezüst Signum Laudist. A háború után a budapesti Szent János kórház Bőr- és Nemibetegosztályára került. ${ }^{2}$ 1921-1922-ben néhány hónapig a szegedi (a Szegedre költözött kolozsvári) orvoskaron tanársegéd. 1922. február l-jétől a hódmezővásárhelyi kórház akkor létrehozott Bőr- és Nemibeteg Osztályának fóorvosa. Ekkor még nincs huszonkilenc éves. 1933ban a szegedi orvoskaron magántanárrá képesítik. 1940től az I. bécsi döntéssel ismét Magyarországhoz tartozó Kassán a kórház Bőr- és Nemibeteg Osztályát vezeti. 1942. november 21-én halt meg a II. bécsi döntéssel ismét Magyarországhoz tartozó szülővárosában, Kolozsvárott, ahová egyetemi előadásának megtartására utazott. Édesanyja házában éri szívroham. Még nem volt ötvenéves.

A német Paul Erlich orvos, a tudományos gyógyszerkutatás, a kemoterápia megalapítója, az élettani-orvosi Nobel-díj 1908. évi díjazottja, 1910-ben, hétévnyi kutatás, a 606. próbálkozás eredményeként megtalálta a szifilisz (lues, vérbaj) nevü nemi betegség első hatékony gyógyszerét. Egy arzenobenzol-származékot, amelyet Salvarsannak nevezett, s amelynek - mint szinte minden gyógyszernek - van mellékhatása, amelyre a beteg gyógyszerezésénél az orvosnak figyelnie kell. És persze drága volt az 1930-as évek elejéig, amikor is megjelent lényegesen olcsóbban előállítható változata, a Solusalvarsan. ${ }^{3}$ Szentkirályi azt tapasztalta, hogy a cigányok arzenobenzol-érzékenysége nagyfokú. De ne szaladjunk annyira előre! Az alábbiakban dr. Szentkirályi Zsigmond Orvostudományi Szemlében megjelent cikkét ismertetem.

\footnotetext{
${ }^{1}$ Népegészségügy, 1942. 1440-1441. oldal. A nekrológ szerzője dr. Domahidy György, az ifjabb pályatárs a nemi betegségek elleni küzdelemben. 1936-tól Szabolcs vármegye tiszti föorvosa.

2 Az osztály a régi Szent János kórház Széna téri - a mai buszpályaudvar helyén álló - épületében múködött. Budapest 1944-1945. évi ostromakor rommá lőtték, s csak 1949-ben döntöttek arról, hogy nem építik újjá, hanem eltakarítják a romokat. Ez volt a Szent János kórház 1897-1898-ig, mikor elkészült a mai helyén álló új.

${ }^{3}$ solu = solution; magyarul: megoldás
}

A magyarországi cigányok venereás (nemi beteg) fertőzöttségét elöször a debreceni orvoskar közegészségügyi intézete vizsgálta az 1930-as évek legelején. Bihar megye öt járásában 1046 vándorcigányt vizsgáltak. A vándorcigányokat akként határozták meg, hogy nem tartoznak közéjük a „[m]uzsikus és más rendesebb, állandóbb foglalkozású cigányok, akik mintegy átmenetet képeznek a vándorcigányok és a falu lakossága között”. A szifiliszes fertőzöttségre Wassermann-vizsgálattal szürtek, aminek alapján az esetek 12,8\%-ában erősen valószínüsítették a fertőzöttséget (a nőknél 13,3\%, férfiaknál 12,4\%), köztük voltak egészen fiatal, 10 évesnél fiatalabb gyermekek is. Ez az arány több mint háromszorosa volt a becsült országos átlagnak $(3,66 \%){ }^{4}$

1940-ben Szentkirályi dr. Árvayné Szentkirályi Irmával a kassai cigányokat vizsgálva 26,8\%-ot, míg néhány hónappal később dr. Habán György kassai kórházi főorvos a Tokaj vidéki cigányoknál $15 \%$-ot talált. Szentkirályi és Árvainé később a kassai járás községeiben lakó cigányokat is vizsgálta, fertőzöttségüket kisebbnek találta a kassaiaknál, sőt egyes községekben 10\%-nál kisebb értékeket is kaptak. (E vizsgálat eredményeit, szemben a kassaival, nem tették közzé - legalábbis orvosi szaklapban.) A szifilisz mellett a kankó (gonorrhoea, tripper) -fertőzöttségre is kíváncsiak lettek volna, de arról „főleg a nók vizsgálatának nehézségei miatt pontos adatokat szerezni nem sikerült”, ám úgy hiszik, hogy az „nem sokkal nagyobb, mint a velük egy anyagi helyzetben élő és ugyanolyan múveltségi színvonalon lévő proletár elemeké”.

A kassai cigányok vizsgálata nem volt könnyü - panaszkodott Szentkirályi főorvos. A tiszti főorvos írásbeli felhívására a körülbelül 1100 kassai cigány közül 926 jelentkezett, s „mindent megtettek, hogy idegeinket próbára tegyék". Vizsgálatuk során 232 szifiliszest és kankóst találtak, a kankósokat és a kilenc úgynevezett tünetes szifiliszest azonnal kórházba utalták. (Lényegében internálták: a kórházat csak gyógyultan hagyhatták el.) A többieket fokozatosan rendelték kezelésre. A kassai nemibeteg-gondozó munkarendjébe külön „cigánynap”-ot iktattak, s arra behívták a cigánynegyed lakóit személyesen jól ismerő gondozónőt. E rendeléseken megjelentek száma 20-80 fó között ingadozott. E nagy létszámbeli hullámzás okára, panaszkodott, rájönni nem tudtak.

A kilenc kórházba utalt, öt éven aluli szifiliszes gyermek (akiknek kezelésére a kórház gyermekosztályát kérték fel) és az 51 évesnél idősebb nők, illetve a 61 évesnél idősebb férfiak (akiknek injekciós kezeléséról lemondtak, mondván „a közegészségügyet nem veszélyeztetik”, mert - feltételezték - már kellően idősek ahhoz, hogy a fertőzést továbbadják) száma összesen 36 volt, így 196 fó kezelését kellett megoldani. Közülük 65 fö eltünt és felszólításra sem jelent meg, de a megjelent 131 közül is

${ }^{4}$ Dr. Gärtner István, tanársegéd: Serologiai vizsgálatok vándorczigányokon. Népegészségügy, 1932. 269-279. oldal 
csak negyedük csinált végig legalább egy kúrát, a többiek el-elmaradoztak, így azok „kezelése csekély értékú volt”.

A kezelés elhanyagolásának azonban csak részben volt oka a cigányok „fegyelmezetlensége és lelkiismeretlensége" (mármint azok lelkiismeretlensége, akik betegségükről tudva továbbadhatják a fertőzést). A másik részt az jelentette, hogy a cigányok „általában érzékenyek minden orvosi beavatkozással és különösen az injectiós kezeléssel szemben. De emellett az arzenobenzolokkal szemben is feltûnően érzékenyek.”

A 131 fó közül 1 grammnál kevesebb arzenobenzolösszmennyiséget kapott 32 fó, 1-2 gramm közöttit 23 fó, 2-3 gramm közöttit 16 fó, legalább 4,5 grammot (ez a teljes kúra) 30 fó, csak solusalvarsant 23 fö (ők föleg gyerekek), s csak bizmutot kapott 7 fó. (A kombinált kúrák - amikor az arzenobenzol-injekciók mellett voltak bizmutinjekciók is - nincsenek jelezve.)

A 124 arzenobenzol-kezelésben részesült cigány közül 3 bőrgyulladást, 7 sárgaságot, s 10 érbeidegződési zavart kapott - utóbbi lehetetlenné teszi a kezelés változatlan folytatását. Eközben 594 nem cigányt kezeltek, akik közül bőrgyulladást senki, sárgaságot 1 kapott, s 3 fó esetén kellett az arzenobenzol adását befejezni.

A cigányok nagyfokú arzenobenzol-érzékenysége még szembetűnőbb a kassai kórház beteganyagán. Ott 1941ben 48 szifiliszes cigányt kezeltek (köztük titkos - engedélyt [bárcát] nem kért, így rendszeres [rendőr]orvosi ellenőrzés alatt nem álló - prostituáltakat), akik nagy része kassai lakos volt, mégis a kórházba internálták (ez, mint mondja, „megbízhatatlanságuk miatt elengedhetetlen volt”). Rajtuk, érthetően, minél teljesebb értékú kezelést igyekeztek végezni, azonban 8 fớn súlyos bőrgyulladás, 5 fớn sárgaság és 2 fớn egyéb olyan mellékhatás jelentkezett, ami miatt az arzenobenzol adását be kellett szüntetni. „Ezenfelül is voltak kisebb-nagyobb kellemetlenségek (bőrizgalom, urticaria, hányás, láz stb.), amelyek azonban spontán vagy kezelésre lezajlottak anélkül, hogy az arzenobenzol adását be kellett volna szüntetnünk, és így ezeknek sikerült az egy kúrában szükséges mennyiséget mégis megadnunk. 15 cigány intoleranciáját semmiképp sem tudtuk megszüntetni." Közülük többen régebben is részesültek kezelésben, s akkor is így reagáltak.

Amit Szentkirályi, ugyanazt tapasztalta $d r$. Nagy Imre, a munkácsi nemibeteg-gondozó vezetője. Nagy 36 cigányt kezelt, felük volt arzenobenzol-készítménnyel kezelhetó, de 18-ból 8-an „rendetlenül jelentkezett”. Mellékhatásként 3 fönél sárgaság, 2 fönél bőrgyulladás, 1 fơnél mindkettő, 12 fónél egyéb tünet alakult ki.

$\mathrm{Az}$ orvosok természetesen magyarázatot igyekeztek találni a jelenségre. Három hipotézist állítottak fel. Az ok 1. az adagolás hibája, 2. az életviszonyok és a táplálkozás hiányosságai, valamint 3. „faji tulajdonság”-ok.

Az elsőt kizárta, mivel „,[a] legóvatosabb adagolás ellenére feltűnő nagy számban láttunk mérgezési tüneteket”, s ezek „rendesen már a kezelés kezdetén mutatkoztak”. Sőt: „[h]a a gondozóban is olyan rendszeres kezelésre szoríthattuk volna a cigányokat, mint a kórházban, a nem kívánatos mellékhatások száma biztosan több lett volna".

A második inkább, de ez sem bizonyult elégséges magyarázatnak. „A cigányok életszínvonala nagyon alacsony. Rendes foglalkozása csak a cigányzenésznek és annak a kevés munkásnak van, aki rendszeresen vállal munkát, vagy ipart, kereskedést folytat. A túlnyomó többség nem dolgozik vagy csak a végső szükségben keres foglalkozást. Időnként a városi közmunkákban használják fel őket. Máskor koldulásból, élősködésből tartják fenn magukat és közsegélyben, közkonyhai ellátásban részesülnek. A honvédség nagy mennyiségü életmaradékot oszt ki és főleg a cigányok azok, akik a laktanyák környékét ellepik edényeikkel. A táplálkozásuk tehát meglehetősen silány. Vitaminos élelmiszerhez csak nyáron és ősszel jutnak, amikor gyümölcsöt, főzeléket, burgonyát, csöves kukoricát szereznek (sic!) a termőföldeken.” Megjegyzi, hogy „ugyanilyen alacsony színvonalon áll a külvárosi proletároknak nagy tömege is. A kórházi osztály és a nemibeteg-gondozó nem cigánybetegeinek egy része szintén nincs sokkal jobb helyzetben.” A korabeli felfogás szerint az arzenobenzoltúrő képesség hiányának oka „különösen a C. aviteminosis”, a C-vitaminhiány. Ez ellen csak a kórházi betegek esetén tehettek („meghizlalás”), de ez a cigány betegek esetén nem volt hatásos, ellenben „nem cigány betegek életmódjának és élelmezésének megváltoztatása igen hasznosnak mutatkozott".

Mindezek után arra jutottak, hogy „a fajtában keressük az okát ennek a különös tứrőképtelenségnek.” Erről a „színes fajok” esetén kevés adat van. Irodalmi adatok szerint a marokkói bennszülöttek között „az arzenobenzol intolerancia úgyszólván ismeretlen", annak ellenére, rendszeres kezelésük nehézsége miatt újabban igen nagy $(1,0$ gramm $)$ egyszeri adagot kapnak, amit „minden kellemetlenség nélkül elviselnek". Az ázsiai adatok ennél rosszabbak: amerikai szerzők szerint több mint százezer adag arzenobenzol injekcióval történő szervezetbe juttatása után 49 esetben észleltek ártalmat, ebből 26 esetben bőrjelenséget. Japán szerzők 45 ezer adag 3016 betegbe juttatása során 50 esetben ártalmat, ebből 40 esetben bőrelváltozást észleltek. Mindez jóval csekélyebb, mint a cigányok esetén, de a minta csekély, ezért nem mond határozott véleményt. Mivel a cigányok „kétségtelenül ázsiai származásúak, tehát az ázsiai színesek tulajdonságait viselik, ... [ezért] ... nem zárkózhatunk el az elől a gondolat elől, hogy sajátos faji tulajdonságok is rejtőzhetnek az arzenobenzol-túrőképtelenség mögött. A rossz életviszonyok, a táplálkozás hiányai csak fokozzák ezeket a tulajdonságokat.” És ez „a cigányok nemibeteg-gondozásában igen nagy nehézségeket okoz, amit fokoz a cigányság nemi felelősségtudatának teljes hiánya". E nehézségek arra indították Szentkirályit, hogy megkísérelje „a három vegyértékú arzénkészítmények helyett az öt vegyértékúekkel való kezelést”. Ez a Dynarsen. Azt tapasztalta, hogy ezt „a cigányok sokkal jobban 
türik". Dr. Nagy Imre munkácsi fóorvos is ugyanerre jutott. „A jövőre vonatkozólag nagy a fontossága ennek a megállapításnak. Azzal, hogy már kezdettől fogva ötvegyértékü arzennal kezeljük a cigányokat, nemcsak a káros mellékhatásokat előzhetjük meg, de különösen szubjektíve tesszük könnyebbé a cigány számára a kezelést, mert a gluteusba [gluteus maximus = nagyfarizom] adott injekciót nem látja és nem fél annyira tőle."

Emberkísérlet cigányokkal? Kiszolgáltatott és megalázott cigányokkal szemben elkövetett bün versus békében és tisztességben megöregedett bünösök? A történet, mint látjuk, valójában arról szólt, hogy orvosok keresik - és meg is találják! - azt a gyógyszert, amely szifiliszes cigányok gyógyítása során nem okoz mellékhatásokat. Ezt sikerült embereken folyó orvosi kísérletté „átértelmezni”.

Vajon a cikket jegyző, a cigány közéletben amúgy ismeretlen Gervai Gábor - valószínúleg álnév -, aki biztosan olvasta az eredeti közleményt, miért tartotta fontosnak „emberkísérlet”-té kiforgatni az orvosok szifiliszes cigányok gyógyítására tett erőfeszítéseit? S nem mellékesen fény derült arra, hogy Katz Katalin szerzőként nem vette a fáradságot, hogy könyvének írásakor az eredeti forrásokat használja, s ne azok meghamisításait.

(Németh György, e-mail: n.gyorgy@t-online.hu) 